\title{
Peyzaj Mimarlığı Açısından Mekânsal Bellek Kavramı Olarak Hüzün Turizmi
}

\author{
Mesut GÜZEL ${ }^{1 *}$, Ömer ATABEYOĞLU ${ }^{1}$ \\ ${ }^{1}$ Ordu Üniversitesi, Ziraat Fakültesi, Peyzaj Mimarlığg Bölümü, 52200, Ordu
}

\section{Öz}

Alternatif turizm türlerinden biri olan "hüzün turizmi”, toplu ya da bireysel ölümlerin gerçekleştiği alanlara ve anıt niteliğindeki mekânlara yapılan seyahatlerdir. Savaşta yitirilenler anısına anıtların ve anıt parkların inşa edilmesi, cezaevlerinin müzeye dönüştürülmesi, dini ve kültürel açıdan çeşitli olaylara tanıklık ettiği varsayılan alanların ziyaretçi akınına uğraması bu alanlara "bellek mekânı" niteliği kazandırmakta ve "hüzün turizmi" kavramını destekleyen olgular olarak karşımıza çıkmaktadır. Bellek mekânlar, peyzaj mimarlığı açısından da önemli rekreasyon ve turizm alanlarıdır. Bu kapsamda çalışmanın amacı; henüz yeni bir kavram olan bellek mekân olgusunu örnekleri ile inceleyerek, Türkiye'deki durumunu peyzaj mimarlığı açısından değerlendirmektir. Çalışmada; peyzaj mimarlığı bakış açısından bellek mekânları, mekânsal bellek ve hüzün turizmi kavramları açıklanmış, mekânsal bellek ve hüzün turizmi arasındaki ilişki incelenmiş, kolektif belleğin ifadesi ve taşıyıcısı olarak hüzün turizmi olgusu üzerinde durulmuştur. Bu kapsamdaki turizm alanları doğal afet, önemli kişi, kaza, toplumsal olay ve savaş kategorileri altında incelenmiştir. Çalışmada, dünyanın çeşitli yerlerindeki ve Türkiye'deki örnekleri incelenmiş ve Türkiye'nin bu kapsamındaki potansiyeli değerlendirmeye alınmıştır. Sonuç olarak, Türkiye'nin bu anlamda önemli bir turizm potansiyeline sahip olduğu tespit edilmiştir. Ayrıca bu potansiyelin doğru bir şekilde değerlendirilebilmesi için, tasarımcı ve yöneticiler odağında öneriler geliştirilmiştir.

Anahtar Kelimeler: Mekânsal bellek, bellek mekânı, hüzün turizmi, peyzaj mimarlığı.

\section{Dark Tourism as a Spatial Memory Concept in Terms of Landscape Architecture}

\begin{abstract}
"Dark tourism," which is one of the alternative tourism types, is travels to areas where collective or individual deaths occur and to places like monuments. The construction of monuments and memorial parks in memory of those who were lost in the war, the conversion of prisons into museums, the influx of visitors to the areas assumed to have witnessed various religious and cultural events, make these areas a "memory space" and appear as phenomena that support the concept of "dark tourism." Memory spaces are also important recreation and tourism areas in terms of landscape architecture. In this context, the study aims to evaluate the situation in Turkey in terms of landscape architecture by examining the phenomenon of memory space, which is a new concept, with examples. In the study; from the perspective of landscape architecture, the concepts of memory spaces, spatial memory and dark tourism are explained, the relationship between spatial memory and dark tourism has been examined, and the phenomenon of dark tourism as the expression and carrier of collective memory has been emphasized. Tourism areas within this scope have been examined under the categories of natural disasters, important people, accidents, social event and war. In the study, the examples in various parts of the world and in Turkey were examined and the potential of Turkey in this context was evaluated. As a result, it has been determined that Turkey has an important tourism potential in this sense. In addition, in order to evaluate this potential correctly, suggestions have been developed with the focus of designers and administrators.
\end{abstract}

Keywords: Spatial memory, memory place, dark tourism, landscape architecture. 


\section{Giriş}

Tarih boyunca toplumların yaşadığı savaş ve çatışmalar, acı olaylar, ölümler, doğal afetler ve yaşanan maddimanevi kayıplar insanları ve dolayısıyla toplumları etkilemiştir. Bunun sonucu olarak da geçmişteki acı olayları ve kayıpları belirli dönemlerde anmak, olayın bilgisini gelecek nesillere aktarmak gibi amaçlarla filmler çekilmiş, tiyatro oyunları yazılmış, besteler yapılmış ve şarkılar söylenmiştir. Yine aynı amaçlar doğrultusunda çeşitli mekânlar oluşturulmuştur.

Geçmiş deneyimlerin ve hatıraların cisimleştiği mekânlar yaratma isteği (Assmann, 2015) insanları çeşitli anıtlar, müzeler, parklar ve meydanlar yapma noktasında cesaretlendirir. Bunun sonucunda oluşturulan mekânlar, var oluşları ve içerdikleri unsurlar sebebiyle adeta toplumun geçmiş kayıtlarının tutulduğu bir bellek mekânına dönüşür. Bu bağlamda; toplu ya da bireysel ölümlerin gerçekleştiği alanlara ve anıt niteliğindeki mekânlara yapılan seyahatleri ifade eden hüzün turizmi olgusu ile bellek mekânı kavramlarının büyük ölçüde örtüştüğünü görmek mümkündür.

Bu çalışma; bellek mekânı kavramı ile hüzün turizmi arasındaki ilişkiyi ve hüzün turizmi merkezlerinin toplumun geçmiş tecrübe ve anılarının kaydedilmesinde ve toplumsal belleğin canlı tutulmasında ne gibi bir rolü olduğunu açıklamayı amaçlar. Bununla birlikte, Türkiye ve dünyadaki bellek mekânların mevcut durumunu ve ülkemizdeki potansiyel hüzün turizmi alanlarının planlanması ve tasarlanması noktasında öneriler getirmek de amaçlanmıştır. Turizm ve peyzaj mimarlığı disiplinlerine ait iki kavramın yakın ilişkisinin anlaşılmasında ve bellek mekânların toplumlar için öneminin vurgulanması noktasında da önemlidir. Ayrıca, bu çalışma ile köklü bir tarihsel geçmişe sahip olan ülkemiz coğrafyasındaki mevcut hüzün turizmi merkezlerinin ve potansiyel alanların planlanması ve tasarlanmasında peyzaj mimarlığı meslek disiplininin ne denli önemli olduğu ortaya konulmuştur.

\section{Kavramsal Çerçeve}

\subsection{Bellek ve Kolektif Bellek}

Birey, dış dünyadan gelen bilgi ve uyarıcıları duyu organları aracılığg ile algılar. Bellek; tüm bu bilgilerin, yaşanan deneyimlerin ve bu deneyimlerin bireyde oluşturduğu duyguların, öğrenilen konu ve kavramların zihinde saklanması, gerektiğinde hatırlanması olarak tanımlanmaktadır (Taşören, 2008; Mert, 2017; TDK, 2019).

Belleğin yalnızca bireye özgü bir özellik olmadığı, aynı zamanda toplumsal bir olgu olduğu yönündeki düşünceler kolektif bellek kavramının ortaya çıkmasına neden olmuştur. Birey yaşamını toplum içinde sürdürdüğünden hem ortak yaşamın getirdiği zorlukları gö̆üsler, hem de ait olduğu toplumun inanç, değer ve kültür birikimini koruyarak gelecek nesillere aktarır. Toplumun bütününü ilgilendiren bir olay yaşandığında, bu olayın tüm bilgisi toplumun belleğinde yer eder. Sonuç olarak bu bilgiler bireylerce paylaşıldığı sürece kolektif bellek üzerinde pekişir ve böylece kuşaktan kuşağa aktarılır. Kolektif bellek, kolektif bir olgu olmasının yanında kendisini bireylerin eylem ve söylemlerinde gösterir ve aynı zamanda bireyler de kolektif bellekten beslenir (Kansteiner, 2002; Öymen Özak ve Pulat Gökmen, 2009; Atik ve Bilginer Erdoğan, 2014).

Kolektif bellek kavramının tek bir akademik disipline ait olmaması; sosyoloji, antropoloji, psikoloji ve tarih bilimi gibi diğer disiplinlerce de sıkça kullanılması kavramın tanımlanmasını güçleştiren bir olgu olarak ortaya çıkar (Wertsch and Roediger, 2008). Sonuç olarak farklı disiplinlere ait kolektif bellek tanımları yapılmış olsa da bu kavram, ortak yaşanmışlıkları olan bireylerin bir araya gelerek oluşturduğu toplumların ortak belleği olarak açıklanabilir.

\subsection{Mekân-Bellek İlişkisi ve Bellek Mekânları}

Bireyin ve toplumun, oluşumlarındaki süreçleri ve yaşanmışlıkları ne oranda hatırladığı ya da hatırlama biçimi, onun kültürel yapısına ilişkin önemli bir gösterge niteliğindedir. Bu nedenle bireysel ve kolektif bellekte, bilinçli olarak biriktirilen her türlü unsurun (mekân, olay, kişi, ses, görüntü, koku vb.) bir şekilde kaydedilerek gelecek kuşaklara aktarılması büyük önem taşır (Ünlü, 2017). Assmann (2015), geçmiş deneyimlere dair hatırlanan her bir ögenin mutlaka bir mekâna dayandığından bahsetmektedir. Deneyimin içinde gerçekleştiği mekân, belleğe deneyimle birlikte kodlanır. Bir aile için ev, kırsal kesimde yaşayanlar için köy, kentliler için kentler ve bir coğrafyada yaşayanlar için o coğrafi bölge mekâna ilişkin hatırlamanın çerçevesini oluşturur (Assmann, 2015). Günaçan ve Erdoğan'a (2018) göre; bellek ve mekân arasında iç içe geçmiş bir ilişki vardır ve toplumlara ait kolektif belleğinin oluşturulmasında ve korunmasında mekân unsuru bir araç olarak kullanılır. 
Toplumlar sosyokültürel kimliklerini somutlaştıran, geçmiş deneyimlerin ve hatıraların cisimleştiği mekânlar yaratmak ister (Assmann, 2015; Günaçan ve Erdoğan, 2018). Bu cisimleştirme çoğu zaman, mekâna "bellek mekânı" niteliği kazandıran anıtsal yapılar, heykel ve plastik objeler ya da mezar taşları kullanılarak yapılır. Assmann'ın (2015) bahsettiği "hatırlama figürlerinin belirli zamanlarda güncelleştirilmesi” ise belirli dönemlerdeki anma törenleri ile yapılabildiği gibi, mekânın kendisinin deneyimlenmesi yoluyla da yapılabilmektedir. Geçmiş deneyimlerin ve hatıraların cisimleştiği sembolik mekânlar olarak karşımıza bellek mekânı olgusu çıkar. Erbaş Gürler ve Özer (2013) bellek mekânı kavramını, "geçmişte gerçekleşmiş olayları, kamusal alanlarda fiziksel temsiliyetleri ile ortak bellekte canlı tutmayı mümkün kılan peyzajlar" olarak tanımlamaktadır. Toplumsal belleğin korunabilmesi noktasında mekânın oldukça önemli olduğu üzerinde duran Günaçan ve Erdoğan (2018) da bellek mekânların, simgesel bir mekân olarak toplumsal hafizanın diri tutulmasını sağladığını belirtmektedir. Bellek mekânların bir diğer özelliği de içerisine girilip deneyimlendiğinde, o an için zamanı durdurması ve içerisinde barındırdığı somut ve soyut değerler ile geçmişte yaşanmış olayları bireye hatırlatmasıdır (Günaçan ve Erdoğan, 2018). Benzer şekilde Atalay da (2018) bellek mekânlarının; geçmişin bilgisinin aktarılmasına, olaya ilişkin farkındalık ve farklı bakış açıları kazandırılmasına, mekânı fiziksel olarak deneyimleyenler arasında duygu paylaşımına olanak tanıdığını belirtmektedir.

\subsection{Bellek Mekânlarının Nitelikleri}

Bir mekân, süreç içerisinde yaşanan olumlu ya da olumsuz çeşitli olayların ve ortak bir yaşanmışlıklar silsilesinin sonucu olarak "bellek mekânı” niteliği kazanmaktadır (Nora, 2006). Bellek mekânlarının genellikle sahip olduğu temel nitelikler şöyle sıralanabilir (Nora, 2006; Keskin, 2014; Günaçan ve Erdoğan, 2018):

- Bellek mekânları; toplumların ortak geçmişleri ile gelecekleri arasında bir köprü vazifesi görürler.

- Çok farklı nitelikteki alanlar bellek mekânı özelliği taşıyabilir. Örneğin; müzeler, anıtlar, bireysel ya da toplu mezarlıklar, inanç yapıları, kent meydanları, bulvar, cadde ve sokaklar, parklar toplumların ortak geçmişinin belirli ölçülerde kaydedildiği bellek mekânlarıdır. Özellikle müzeler; toplumların geçmişine ait unsurların bir araya getirilerek korunduğu ve sergilendiği mekânlar olmaları nedeniyle en iyi bellek mekânı örnekleridir.

- Bellek mekânları doğrudan bir hatırlatma işlevi taşıyan bir anıt olabileceği gibi kültürel peyzajın bir parçası olarak bir cadde ya da sokak da olabilir.

- Bellek mekânı kavramı kolektif olduğu kadar bireysel bir olgudur. Örneğin; bir insanın çocukluğundan yaşlılığına kadar devamlı olarak zaman geçirdiği, çeşitli paylaşımlarda bulunduğu bir park, kolektif anlamda bir bellek mekânı niteliği taşımazken, o kişinin bütün bir hayatına dair anılar o mekânın hafızasında canlı tutuluyor olabilir.

\section{Hüzün Turizmi}

Hüzün turizmi; savaşların, işkence ve soykırımların gerçekleştiği alanlara, büyük insan kayıpları ile sonuçlanmış doğal afet bölgelerine, teknoloji kaynaklı felaketlerin gerçekleştiği alanlara yapılan seyahatler ile bunların anısına inşa edilmiş şehitlik, toplu mezar, anıt ve anıt parklara yapılan ziyaretler olarak tanımlanmaktadır. Ayrıca açlık ve yoksulluk yaşanan bölgelerin ziyaret edilmesi, ünlü kişilerin öldüğü mekânlara yapılan ziyaretler, geçmişte birçok işkence ve ölümlere sahne olmuş hapishanelerin müzeye dönüştürülüp ziyarete açılması, dünyanın sonunun geldiği ve kıyametin yaklaştı̆̆ı varsayımıyla yapılan seyahatler de ölüm ve derin üzüntü ile bağdaştırıldığından hüzün turizmi kapsamında değerlendirilmektedir (Kendle, 2008; Kılıç ve Akyurt, 2011; Çelik, 2017). Seaton (1996), hüzün turizmi kapsamında değerlendirilen seyahatleri 5 ana başlık altında toplamıştır (Tablo 1).

Lennon ve Foley (2000), Dark Tourism the Attraction of Death and Disaster isimli kitabında bu tür turizm faaliyetleri için "dark tourism” ifadesini kullanmıştır. Seaton (1996) bu kavramı karşılayan, Yunan mitolojisinde ölümü ifade eden "thanatos" ve "tourism" sözcüklerinin birleşiminden oluşan "thanatourism" sözcüğünü kullanırken, Blom (2000) "morbid tourism” ifadesini kullanmıştır (Kaya, 2006; Alaeddinoğlu ve Aliağaoğlu, 2007; Kılıç ve Sop, 2011; Kılıç ve Akyurt, 2011; Hartmann, 2014; Birdir vd., 2015; Çelik, 2017). Ülkemizde yapılan bazı çalışmalarda hüzün turizmine karşılık olarak "savaş turizmi” (Doğaner, 2006), "ölüm turizmi”" (Kaya, 2006) "kara turizm" (Yıldız vd., 2015), "karanlık turizm” (Çetinsöz ve Temiz, 2016) gibi kavramlar da kullanılmıştır (Çelik, 2017). 
Tablo 1. Farklı nitelikteki hüzün turizmi alanlarına yapılan seyahatler (Seaton, 1996) ve bu alanlara verilebilecek bazı örnekler.

\begin{tabular}{|c|c|c|}
\hline No & Seyahat türü & Örnek \\
\hline 1 & $\begin{array}{l}\text { Bireysel ya da kitlesel ölümlerin meydana } \\
\text { geldiği bölgelere yapılan seyahatler }\end{array}$ & $\begin{array}{l}\text { Bosna-Hersek'te Srebrenitsa Soykırımı'nın } \\
\text { gerceklestiği alanlar; } 11 \text { Eylül Anıtı }\end{array}$ \\
\hline 2 & $\begin{array}{l}\text { Mezarlık ya da anıtları görmek için yapılan } \\
\text { seyahatler }\end{array}$ & $\begin{array}{l}\text { Gelibolu Yarımadası; Çanakkale Şehitler } \\
\text { Abidesi; Hiroşima Barış Anıtı Parkı }\end{array}$ \\
\hline 3 & $\begin{array}{l}\text { Ölümü sembolize eden silahlar ya da ölenlere ait } \\
\text { essyalar gibi ölümle bağlantılı malzemelerin } \\
\text { sergilendiği yerlere yapılan seyahatler }\end{array}$ & Auschwitz-Birkenau Nazi Toplama Kampı \\
\hline 4 & $\begin{array}{l}\text { Dini figürlerin ölümünü temsil eden ve kutsallık } \\
\text { atfedilen alanlara yapılan seyahatler }\end{array}$ & $\begin{array}{l}\text { Mevlâna Türbesi; Kerbela Bölgesi; } \\
\text { Abdurrahman Gazi Türbesi ve çeşitli türbeler }\end{array}$ \\
\hline 5 & $\begin{array}{l}\text { Yargılanmaları sonucunda idam cezasına } \\
\text { çarptırılan insanların infazına tanıklık etmek için } \\
\text { yapılan seyahatler }\end{array}$ & $\begin{array}{l}\text { Yassiada; Tarihi Sinop Cezaevi; } \\
\text { Alcatraz Adası Hapishanesi }\end{array}$ \\
\hline
\end{tabular}

\subsection{Hüzün Turizminin Etki ve Motivasyonları}

Hüzün turizmi olarak değerlendirilen seyahat ve ziyaretlerin insanlar üzerinde nasıl bir etki bıraktığıyla ilgili yapılan çalışmalar özellikle "katarsis" kavramı üzerinde durmuştur. Aristo'nun eserlerinde kullanılan bu kavram temel olarak ruhun arınması, temizlenme, duygusal gerilimin sonlandırılması ve rahatlama anlamlarına gelir. Bir hüzün turizmi noktasını tüm duyularıyla deneyimleyen birey kendisini olayın kahramanları ile özdeşleştirmekte, adeta onlarla birlikte savaşmakta, zafer kazanmakta, işkence görmekte, acı çekmekte ve tüm bunların sonucunda da ruhsal olarak kendisini arınmış hissederek, huzura ermektedir. Yaşanılan bu içsel üzüntü ve hüzün duygusu ziyaretçilerin bu tip seyahatlerden beklentisini karşılaşmakta ve seyahatin tatmin edicilik düzeyini arttırmaktadır (Gürel ve Muter, 2007; Kılıç ve Akyurt, 2011; Kılıç ve Sop, 2011; Alılı, 2017).

Kılıç ve Sop'a (2011) göre; bir doğal afet bölgesinin ziyaret edilmesi neticesinde elde edilecek olan kazanım, doğanın yıkıcı gücünün ziyaretçiler tarafından fark edilmesidir. Böylece, örneğin Çernobil'de meydana gelen nükleer reaktör kazasına ait kalıntıların sergilenmesi teknolojinin doğru kullanılmadığında ne kadar yıkıcı sonuçlara sebep olabileceği konusunda ziyaretçilerin uyarılmasını sağlar. Tarihi Sinop Cezaevi Müzesi'ne yapılan bir ziyarette ziyaretçilerin elde edeceği kazanım ise; ziyaretçinin kendisini bir mahkûm olarak hayal etmesi ve bu tutsaklık duygusunun ne denli zor olabileceğini benliğinde deneyimlemesidir.

Tarihsel süreç içerisinde yaşanan tüm olumsuz olaylar, savaş ve çatı̧̧malar, doğal afetler ve bunların sonucunda meydana gelen kayıplar bireylerin ve içinde yaşadıkları toplumların belleklerinde derin izler bırakır. Tüm bu olayların gerçekleştiği mekân ve alanları yerinde deneyimleyebilme, yaşanan olayları benliklerinde hissedebilme ve olayın kahramanları ile empati kurabilme arzusu, ölümlerin hangi sebeplerle ve yöntemlerle gerçekleştiğini merak etme duygusu, insanları hüzün turizmi kapsamında değerlendirilen seyahatlere yönelten temel motivasyonlardır (Varol, 2015; Hidır ve Somuncu, 2018).

Çanakkale Gelibolu Yarımadası Tarihi Milli Parkı ziyaretçilerinin seyahat motivasyonları üzerine bir araştırma yürüten Kurnaz, Çeken ve Kılıç (2013) ziyaretçileri hüzün turizmine motive eden sebeplerin; şehitleri anmak ve onlar için dua etmek, savaşın heyecanını yaşamak, savaşan insanların duygularını hissetmeye çalışmak, tarihe tanıklık etmek ve bölgede gerçekleșen olaylar hakkında yerinde bilgi edinmek gibi sebepler olduğunu tespit etmiştir.

Öztürk (2016); Tarihi Sinop Cezaevi Müzesi örneğinde yaptı̆̆ı araştırmada, ziyaretçileri hüzün turizmine motive eden en önemli duyguların "anlama ve merak duygusu" olduğunu ortaya koymuştur. Benzer bir araştırmayı ABD Houston'da yer alan Holokost Müzesi örneği üzerinden yapan Yuill (2003), müze ziyaretçilerinin ana motivasyon kaynağının tarihsel süreçte yaşanan olayların hatıllanması ve daha iyi okunarak anlaşılması, eğitim yoluyla gelecek nesillere aktarılması olduğu sonucuna varmıştır.

Bazı çalışmalarda hüzün turizmi kapsamında yapılan seyahatlerin, ölümün belirsizliğinden kaynaklanan korkutucu duygunun üzerine giderek onunla yüzleşme ve kendilerini ölüm olayına hazırlama güdüsüyle yapıldığı ifade edilmektedir (Seaton, 1996; Stone and Sharpley, 2008; Alıl1, 2018). Bununla birlikte Kaya (2006), Gelibolu Yarımadası Tarihi Milli Parkı'nı ziyaret eden turistler üzerinden yaptığı araştırmada ana itici gücün ölümle yüzleşme isteği ya da ölüme ilgi duyma olmadığını, ziyaret sebeplerinin temelde kültür ve mirasa sahip çıkma olduğunu bulgulamıştır. Benzer şekilde Okuyucu ve Erol da (2018) çalışmalarında, inceledikleri hüzün turizmi 
noktasını ziyaret eden ziyaretçilerin motivasyon kaynaklarından en önemlisinin tarihi mirasa duydukları saygı olduğunu tespit etmiştir.

Hüzün turizmi kapsamında gerçekleştirilen tüm seyahat ve ziyaretlerin hangi motivasyonlar ile yapıldığı, seyahatin ya da ziyaretin yapıldı̆̆ı mekânın niteliğine göre farklılaşmaktadır. Bir seyahat yalnızca "tarihin sayfalarında gezinme, savaşın heyecanını yaşama ve kazanılan zaferlerden dolayı gurur duyma" motivasyonuyla (Kozak ve Bahçe, 2012; Kurnaz, Çeken ve Kılıç, 2013) yapılabildiği gibi bütünüyle merak ve tarihe ilgi duyma (Yuill, 2003; Öztürk, 2016) ya da olayın tanıklarıyla empati kurma ve duygusal olarak yakınlık duyma (Chang, 2014; Birdir vd., 2015) amacıyla da yapılabilmektedir. Farklı nitelikteki mekân ve alanlara yapılan seyahatler incelendiğinde çok daha farklı motivasyon kaynakları da tespit edilebilir.

Hüzün turizmi kavramının kapsamı ve ziyaretçilerin motivasyonlarına bakıldığında hüzün turizmi alanlarının oluşturulma amaçları şu şekilde özetlenebilir:

- Bir alanın tarihsel geçmişini, bu alanda yaşanmış olan süreç ve olayların bilgisini eğitim yoluyla gelecek nesillere aktarmak,

- Ulusların geçmişlerinde kazandıkları zaferlerle övünmesini ve yenilgilerinden dersler çıkarmasını sağlamak,

- Özellikle savaş ve soykırımlara sahne olmuş alanların turizme kazandırılması ile ziyaretçilerde evrensel barış bilincini uyandırmak,

- Ziyaretçilerdeki, geçmişe ve geçmişte yaşanan olaylara dair merak duygusunu gidermek,

- Ziyaretçileri tüm canlılar için kaçınılmaz olan ölüm olgusuyla yüzleştirmek,

- Toplumların geçmişlerinde önemli işlere imza atmış olan şahsiyetleri anmak,

- Geçmiş olayların kahramanları ile duygudaşlık kurdurarak ziyaretçilerde ruhsal bir arınma ve rahatlama hissi uyandirmak,

- Alanın kaynak değerlerini yansıtan resim ve fotoğraf sergileri, ölenlere ait eşya ve kıyafet sergileri, söyleşi ve toplantılar gibi kültürel ve bilimsel faaliyetlere ev sahipliği yapacak alanlar oluşturmak.

\subsection{Peyzaj Değeri ve Peyzaj Tasarımı Bakımından Hüzün Turizmi Alanları}

Turizm faaliyetleri ne şekilde yapılırsa yapılsın beraberinde pek çok beklenti getirmektedir. Bu beklentiler, ziyaretçilerin ziyaret nedenlerine göre çeşitlenir ve ziyaretçi taleplerini karşılamak üzere organize olur. Böylece turizm faaliyeti; faaliyetin gerçekleştiği bölgeye, faaliyeti organize edenlere ve ziyaretçilere farklı kazançlar sağlar. Bu eksende düşünüldüğünde turizm faaliyeti geniş çaplı maddi ve manevi boyutları olan bir organizasyona dönüşür. Pek çok turizm etkinliği ve turizm alanı için vazgeçilmez öğeler; doğa, mimari öğeler, doğru kullanılmış çevre ve iyi bir peyzaj tasarımıdır. Böylece turizm faaliyeti, kendine özgü konusu ve kurgusu ile diğerlerinden farklılaşan, turizm konusuna özel hazırlanmış ve ziyaret amacına uygun olanaklar yaratan bir ortamda sunabilme kabiliyetine ulaşır.

Hüzün turizmi alanları için benimsenen tasarım yaklaşımları, kaynak değeri ya da ziyaret motivasyonundan bağımsız olarak hem bir ihtiyaç hem de gerekliliktir. Esasında tüm hüzün turizmi alanları için peyzaj değerinin artırılması pek çok işlevi birlikte getirdiği gibi, kaynak değerlerini vurgulayıcı ve güçlendirici bir olgu olarak da ön plana çıkar. Bu güçlendirme etkisi sayesinde turizm öğesi, hem daha çarpıcı bir şekilde kendini gösterme imkânı bulur, hem de kent için yeni işlevler ve olanaklar sunan bir alana dönüşür. Hüzün turizmi alanları, kendilerine yüklenen tüm anlamların yanı sıra önemli bir çevresel etki potansiyeline sahiptir. Bazıları kent içinde olmakla birlikte, pek çok hüzün turizmi alanının kentlere nispeten uzak oluşu, bu alanları ziyaretçiler için bazı olanakları sağlar hale getirir. Böylece, alanın hassasiyetini zedelemeden, manevi değerlere saygılı kalarak ve odak konunun önüne geçmeyerek ziyaretçiye alternatifler sunar. Bir taraftan ziyaretçilere hizmet ederken, diğer taraftan da ziyaretlerin süresinin uzamasını ve ziyaretlerin tekrarlanmasını garantiler. Hüzün turizmi alanları; anma ve hatırlatma odaklı mekânlar olsa da eğitim, tarih bilgisi, kültür aktarımı, dönemi yaşayarak hatıralara ortak olma, dikkat çekme, tehlikeyi vurgulama gibi pek çok sosyal sorumluluğun yerine getirilmesinde önemli bir görev üstlenir. Bu noktada dış mekân kullanımı ve peyzaj tasarımının önemi büyüktür. Turizm konusuna göre alanda açık hava müzesi, açık hava eğitim alanları, dinlenme ve toplanma alanları, karşılama mekânları, tören ve anıt alanları, dönemlerin ya da alanda cereyan eden olayların tekrar canlandırıldı̆̆ı sahneler, sembolik öğeler gibi konu odaklı detaylar ile yapısal ve bitkisel tasarımlar bir bütünlük oluşturur. Böylece dış mekân kullanımları ve peyzaj tasarımı hem konunun kendisine katkı ve destek sağlarken, hem de yaygın etkisi ile içinde yer aldığ kentsel ya da kırsal alanın nitelik kazanmasını sağlar.

Esasında hüzün turizmi alanları ya da bellek mekân niteliğindeki alanlar peyzaj tasarımları bakımından önemli avantajlara sahiptir. Bu alanlar kendilerine has anlamlarının getirdiği temalara sahiptirler. Bu nedenle de peyzaj 
tasarımı çalışmaları için uyulması gereken temalar açık ve nettir. Turizm alanlarındaki peyzaj çalışmaları, her türden yaşam alanına sağladığı fonksiyonel ve estetik katkılara ek olarak hüzün turizmi alanlarına da niteliğine uygun olarak aşağıda sıralanan katkıları sunmaktadır:

- Alanın niteliğini yükselterek alana değer katar,

- Alan konusuna uygun olarak tarih öğrenimine, hatırlamaya, ders çıkartmaya ve kültür aktarımına katkı sağlar,

- Fonksiyonel ve estetik katkı sağlar,

- Turizmin konusunu, anlatım ve ifadesini güçlendirir,

- Sembolik anlamlar katar ve sembolik anlamları tamamlar,

- Döneme uygun ortamın tesis edilmesine katkı sağlar,

- Gizem oluşturur, çekim etkisi sağlar,

- Alternatif kullanımlar kazandırır,

- Özenle düzenlenmiş bir çevre ile toplumun hatıralarına saygı gösterilir,

- Kentsel ve çevresel niteliğe katkı sağlar.

\subsection{Dünyada Hüzün Turizmi}

Dünya genelinde ölüm ve ölümle bağlantılı diğer olguları içeren, yılın her döneminde çok sayıda ziyaretçiyi ağırlayan ve bulunduğu ülkenin ekonomisine önemli ölçüde katkılar sağlayan birçok hüzün turizmi noktası bulunmaktadır (Tablo 2). Bu alanların bazıları dünya çapında etki yaratmış düzeyde bellek mekânlarken, bazıları da o millet için anlamı çok daha derin ve tarihlerinde yer etmiş alanlardır. Bu bellek mekânlar; doğal afet, önemli kişi, savaş/terör, toplumsal olay/suç ve kaza kategorilerinde toplanmıştır. Alanların, milyonlarla ifade edilen sayılarla ziyaretçi çekmesi bu anıların ne deni ilgi oluşturduğu ve toplumsal bellekte ne denli geniş yer ettiğini göstermesi açısından önemlidir.

Tablo 2. Dünya'daki bazı hüzün turizmi alanları (Doğaner, 2006; Kaya, 2006; Robb, 2009; Kılıç ve Akyurt, 2011; Kılıç ve Sop, 2011; Kurnaz vd., 2013; Kurnaz, Çeken ve Kılıç, 2013; Birdir vd., 2015; Varol, 2015; Kurnaz ve Kılıç, 2016; Öztürk, 2016; Alılı, 2017; Alılı, 2017; Çelik, 2017; Hıdır ve Somuncu, 2018; URL-1).

\begin{tabular}{|c|c|c|c|c|c|}
\hline No & Kategori & Alan & Şehir/Bölge & Ziyaretçi & Kapsam \\
\hline 1 & Doğal Afet & $\begin{array}{l}\text { Pompei } \\
\text { Antik Şehir } \\
\text { Kalıntıları }\end{array}$ & İtalya & $\begin{array}{l}2.5 \\
\text { milyon }\end{array}$ & $\begin{array}{l}\text { Pompei şehri, Vezüv Yanardağı'nın } \\
\text { patlaması sonucu yıkılmıştır. }\end{array}$ \\
\hline 2 & Önemli Kişi & $\begin{array}{l}\text { Anne Frank } \\
\text { Müzesi }\end{array}$ & Hollanda & $\begin{array}{l}1.2 \\
\text { milyon }\end{array}$ & $\begin{array}{l}\text { Nazi katliamının sembol isimlerin olan } \\
\text { genç bir kızın yaşadığ } 1 \text { evdir. }\end{array}$ \\
\hline 3 & Savaş/Terör & $\begin{array}{l}\text { Ulusal } 11 \\
\text { Eylül Anıt } \\
\text { ve Müzesi }\end{array}$ & $\mathrm{ABD}$ & $\begin{array}{l}6.6 \\
\text { milyon }\end{array}$ & $\begin{array}{l}2001 \text { yılında Dünya Ticaret } \\
\text { Merkezi'ne gerçekleştirilen saldırıda, } \\
\text { yaklaşı } 3 \text { bin kişi yaşamını } \\
\text { yitirmiştir. }\end{array}$ \\
\hline 4 & Savaş/Terör & $\begin{array}{l}\text { Srebrenitsa } \\
\text { Katliamı } \\
\text { Bölgesi }\end{array}$ & $\begin{array}{l}\text { Bosna- } \\
\text { Hersek }\end{array}$ & $\begin{array}{l}10 \text { binin } \\
\text { üzerinde }\end{array}$ & $\begin{array}{l}1995 \text { yilında birçok sivil Bosnalı, Sirp } \\
\text { güçleri tarafindan Srebrenitsa } \\
\text { bölgesinde katledilmiştir. }\end{array}$ \\
\hline 5 & Savaş/Terör & $\begin{array}{l}\text { Hiroşima } \\
\text { Barış Anıtı } \\
\text { Park1 }\end{array}$ & Japonya & 1 milyon & $\begin{array}{l}\text { Hiroşima ve Nagazaki'ye yapılan } \\
\text { atom bombası saldırısında ölenlerin } \\
\text { anısına yapılmıştır. }\end{array}$ \\
\hline 6 & Savaş/Terör & $\begin{array}{l}\text { Waterloo } \\
\text { Savaş Alanı }\end{array}$ & Belçika & 300 bin & $\begin{array}{l}1815 \text { yılında Belçika'daki Waterloo } \\
\text { kasabası yakınlarında gerçekleşen } \\
\text { savaşın kalıntıları birçok ziyaretçinin } \\
\text { ilgisini çekmektedir. }\end{array}$ \\
\hline 7 & Savaş/Terör & $\begin{array}{l}\text { Terör Evi } \\
\text { Müzesi }\end{array}$ & Macaristan & 360 bin & $\begin{array}{l}2002 \text { yılında kurulan müze içerisinde, } \\
\text { 20. yüzyılda Macaristan'daki baskıcı } \\
\text { yönetimler ile ilgili çeşitli sergiler yer } \\
\text { almaktadır. }\end{array}$ \\
\hline 8 & Savaş/Terör & $\begin{array}{l}\text { Ölüm } \\
\text { Tarlalar1 }\end{array}$ & Kamboçya & 125 bin & $\begin{array}{l}\text { Kamboçya'da 1976-1979 yılları } \\
\text { arasında baskıcı rejim tarafindan } \\
\text { gerçekleştirilen katliamda yaşamınını } \\
\text { yitiren insanların iskeletleri müzelerde } \\
\text { sergilenmektedir. }\end{array}$ \\
\hline
\end{tabular}


Tablo 2. Devam ediyor.

\begin{tabular}{|c|c|c|c|c|c|}
\hline No & Kategori & Alan & Şehir/Bölge & Ziyaretçi & Kapsam \\
\hline 9 & $\begin{array}{l}\text { Toplumsal } \\
\text { Olaylar/Suç }\end{array}$ & $\begin{array}{l}\text { Auschwitz- } \\
\text { Birkenau } \\
\text { Toplama } \\
\text { Kamp1 }\end{array}$ & Polonya & $\begin{array}{l}2.3 \\
\text { milyon }\end{array}$ & $\begin{array}{l}\text { Nazi güçleri tarafindan çoğunluğu } \\
\text { Yahudi olan insanlara sistematik } \\
\text { olarak işkence ve soykırımların } \\
\text { yapıldığı ünlü kamptır. }\end{array}$ \\
\hline 10 & $\begin{array}{l}\text { Toplumsal } \\
\text { Olaylar/Suç }\end{array}$ & $\begin{array}{l}\text { Alcatraz } \\
\text { Hapishanesi }\end{array}$ & $\mathrm{ABD}$ & $\begin{array}{l}1.7 \\
\text { milyon }\end{array}$ & $\begin{array}{l}\text { 1861-1963 y1lları araında aktif olarak } \\
\text { kullanılan ve San Francisco } \\
\text { Körfezi’nde yer alan, ABD’nin en } \\
\text { ünlü hapishanelerinden biridir. }\end{array}$ \\
\hline 11 & $\begin{array}{l}\text { Toplumsal } \\
\text { Olaylar/Suç }\end{array}$ & $\begin{array}{l}\text { Berlin } \\
\text { Yahudi } \\
\text { Müzesi }\end{array}$ & Almanya & 700 bin & $\begin{array}{l}2001 \text { yılında Alman Yahudiler anısına, } \\
\text { Almanya'nın Berlin kentinde açılan } \\
\text { müzedir. }\end{array}$ \\
\hline 12 & $\begin{array}{l}\text { Toplumsal } \\
\text { Olaylar/Suç }\end{array}$ & $\begin{array}{l}\text { Berlin } \\
\text { Duvarı }\end{array}$ & Almanya & $\begin{array}{l}1.1 \\
\text { milyon }\end{array}$ & $\begin{array}{l}\text { 2.Dünya Savaşı sonucunda doğu ve } \\
\text { batı olmak üzere ikiye ayrılan } \\
\text { Almanya'da, insanların diğer tarafa } \\
\text { kaçışı önlemek için } 1961 \text { yılında } \\
\text { Berlin'de inşa edilen duvardır. }\end{array}$ \\
\hline 13 & $\begin{array}{l}\text { Toplumsal } \\
\text { Olaylar/Suç }\end{array}$ & $\begin{array}{l}\text { Holokost } \\
\text { Anıt Müzesi }\end{array}$ & Almanya & & $\begin{array}{l}\text { Naziler tarafından gerçekleştirilen } \\
\text { Yahudi katliamında yaşamını } \\
\text { yitirenler anısına inşa edilen müzedir. }\end{array}$ \\
\hline 14 & $\begin{array}{l}\text { Toplumsal } \\
\text { Olaylar/Suç }\end{array}$ & $\begin{array}{l}\text { Oradour-sur- } \\
\text { Glane } \\
\text { Katliamı } \\
\text { Bölgesi }\end{array}$ & Fransa & $\begin{array}{l}10 \text { binin } \\
\text { üzerinde }\end{array}$ & $\begin{array}{l}1944 \text { yılında Nazi kuvvetlerinin saldırısı } \\
\text { sonucunda } 642 \text { sivil bu bölgede } \\
\text { katledilmiştir. }\end{array}$ \\
\hline 15 & $\begin{array}{l}\text { Toplumsal } \\
\text { Olaylar/Suç }\end{array}$ & $\begin{array}{l}\text { Paris Yeralt1 } \\
\text { Mezarları }\end{array}$ & Fransa & 550 bin & $\begin{array}{l}1788 \text { yılında inşa edilen mezarlıkta } 6 \\
\text { milyon insanın iskeleti sergilenmektedir. }\end{array}$ \\
\hline 16 & Kaza & $\begin{array}{l}\text { Pripyat ve } \\
\text { Çernobil } \\
\text { Bölgesi }\end{array}$ & Ukrayna & 72 bin & $\begin{array}{l}1986 \text { yılında Çernobil Nükleer } \\
\text { Santrali’nde meydana gelen patlama } \\
\text { sonucunda atmosfere çok yüksek miktarda } \\
\text { radyoaktif madde salınmıştır. }\end{array}$ \\
\hline 17 & Kaza & $\begin{array}{l}\text { Costa } \\
\text { Concordia } \\
\text { Batığ1 }\end{array}$ & İtalya & 12 bin & $\begin{array}{l}2012 \text { yılında yan yatarak kısmen batan } \\
\text { yolcu gemisini görmek için birçok insan, } \\
\text { batığın görülebildiği Giglio Adası'nı } \\
\text { ziyaret etmiștir. }\end{array}$ \\
\hline
\end{tabular}

Dünyadaki bellek mekânlar ve hüzün turizmi alanları incelendiğinde, bu alanların bulundukları kentte yaşayanlar ile çoğunlukla ilk elden etkileşim halinde oldukları görülmektedir. Doğrudan kentlerde inşa edilen bellek mekânlar, zaman içerisinde kentlerin önemli bir parçası haline gelmişlerdir. Böylece, kitleler gündelik yaşamları içerisinde bir şekilde kolektif hafızalarını daima canlı tutma firsatını bulmuştur. Bununla birlikte kentler, toplumun tüm yaşanmışlıkları, hatıraları ve toplumsal hafızası ile harmanlanarak zenginleşmiştir. Kentlerin vazgeçilmez bir parçası haline gelen bellek mekânlar, kentleri birer kültürel cazibe noktasına dönüştürerek kent ölçeğinde turizmi artırmış, kentsel turizm de bellek mekân ziyaretlerini desteklemiştir. Bu karşılıklı etkileşimin anlaşılması, bellek mekânların doğru tasarım ve yönetim planları ile sağladığı çok yönlü yararları ortaya koymak açısından da önemlidir. İster bellek mekânlar kentin bir parçasına dönüşmüş, isterse bellek mekânlar kente bir parça olarak eklenmiş olsun, her iki durumda da bellek mekânlar kentin imajı, kültürü, planlaması ve tasarımında estetik ve fonksiyonel bakımdan son derece etkilidir. Hem yapısal hem de bitkisel tasarımlar tüm unsurları ile kenti zenginleştirip, anlam kazandırmaktadır. Böylece kent, tüm yaşanmışlıkları ile uyumlu bütüncül bir kentsel yaklaşımın yansıtıcısı konumuna gelir. Kentin diğer öğeleri ile birlikte bellek mekânlara ait tasarımlar da fonksiyon alternatifleri, kentin tanıtımı ve olumlu imajına katkılar sağlar (Şekil 1).

Bellek mekânlar ister kentsel ister kırsal bir alanda tesis edilmiş olsun, etkili anlam ve konumları nedeniyle kent sembolü ve önemli bir yer işareti (landmark) özelliğine sahiptirler. Bu durumun temel nedeni, dünyadaki bellek mekân örneklerinin çoğunlukla sade, olgun ancak etkili, sansasyonel ve çarpıcı tasarımlar ortaya koymasıdır. Özellikle dış mekân kullanımına olanak tanıyan bellek mekânlar; topoğrafya, plastik öğeler ve geniş çim alanları etkili bir şekilde kullanmaktadır. 

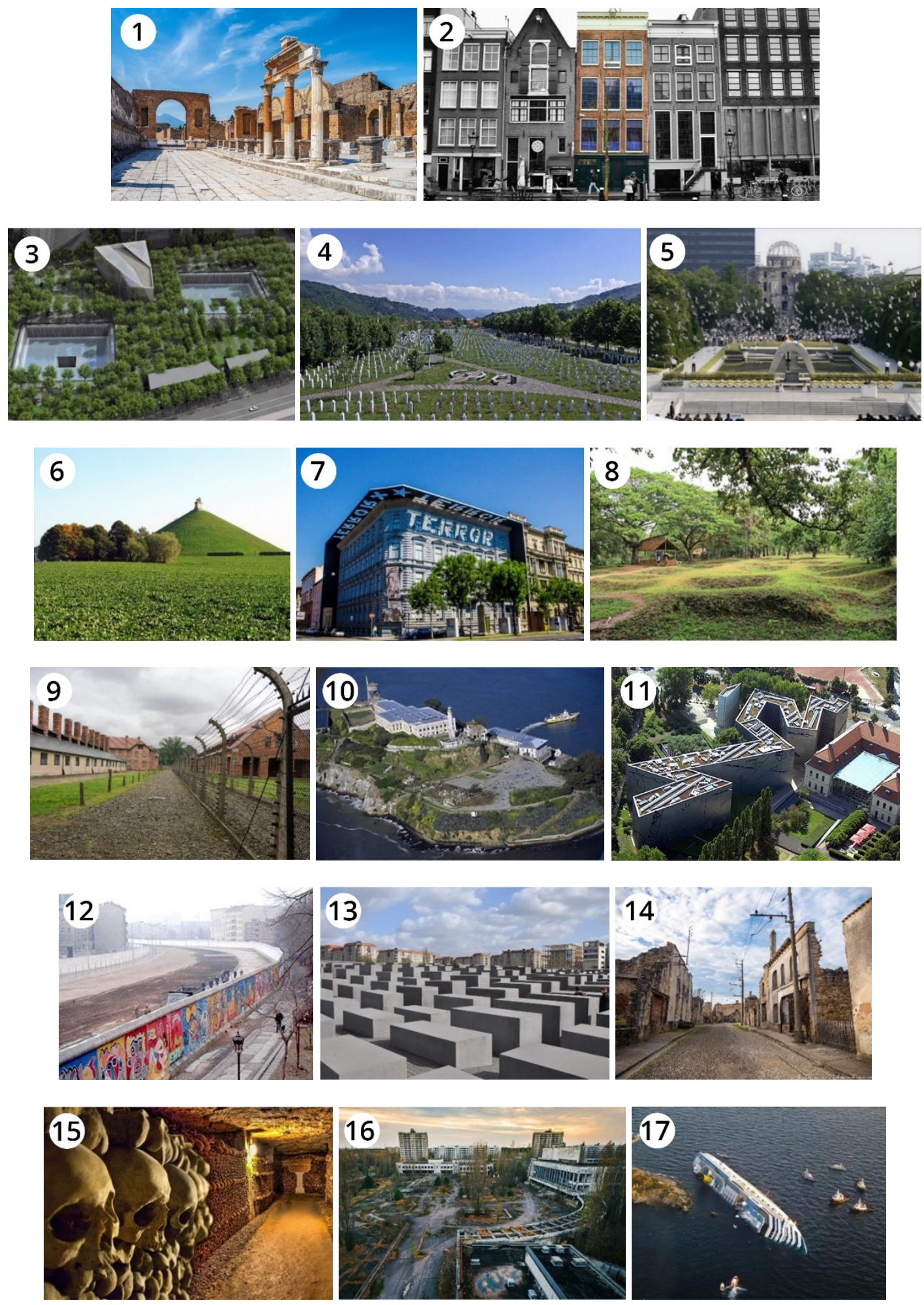

Şekil 1. Dünya'daki bazı hüzün turizmi alanları (URL 2-18).

\subsection{Türkiye'de Hüzün Turizmi}

Sahip olduğu kültür ve tarih unsurlarıyla medeniyetler beşiği kabul edilen Türkiye, tarihin her döneminde çeşitli büyüklüklerde savaşlara, acı olaylara ve doğal afetlere sahne olmasından dolayı hüzün turizminin gerçekleştirilebileceği oldukça fazla potansiyel mekâna sahiptir (Kurnaz, Çeken ve Kılıç, 2013; Öztürk, 2016; Çelik, 2017). Özellikle Gelibolu Yarımadası neredeyse bütünüyle doğal bir bellek mekânı oluşturur (Atalay, 2018) (Tablo 3). 
Türkiye'deki bellek mekânları, çoğunlukla anıtsal nitelikte olmakla birlikte bir kısmı da mevcut yapıların dönüştürüldüğü yerlerdir (Şekil 2). Özellikle yakın tarihimizdeki önemli savaşlara tanıklık etmiş olan alanlara "milli park" statüsü verilerek korunmaları tesis edilmiştir. Bu alanların pek çoğunda, kaynak değerlerini oluşturan olayların yıl dönümlerinde törenler ve anma etkinlikleri gerçekleştirilmektedir. Ülkemizdeki hüzün turizmi ve bellek mekân niteliğindeki alanların çok büyük kısmı milli, dini, topluma mal olmuş ölümler, afetler, kazalar ve siyasi nitelikli alanlardır. Toplumun saygı, şükran ve üzüntüsünü ifade ettiği, kolektif hafızanın sembolü haline gelmiş bu mekânlar, yılın belirli dönemlerinde düzenlenen tören ve anma etkinliklerinde ziyaretçi akınına uğramaktadır. Bununla birlikte keşfetmek, öğrenmek, geçmişin izlerini takip etmek, olayların cereyan ettiği atmosferi yaşamak ve saygı göstermek gibi amaçlar ile yılın her döneminde de ziyaret edilir. Bu nedenle özellikle yerli ve yabancı ziyaretçilerin sürekli ilgi odağında olan seçilmiş örnek bellek mekânlar, daha az bilinen ve yerel örneklerine göre bakımlı, titizlikle organize edilmiş ve çok fonksiyonlu alanlardan bazılarıdır. Örnek olarak seçilmiş ya da değeri ile ön plana çıkmış bu alanların pek çoğu farklı fonksiyon ve organizasyonlarla birlikte dış mekân kullanımları ve peyzaj tasarımlarına da sahiptir. Bu alanların dış mekân tasarımları, özellikle son yıllarda önemli bir yenilenme sürecine girmiştir. Yeni yapılan peyzaj düzenlemeleri ise alanların kaynak değeri ve temasına uygun olarak tasarlanmaktadır. Böylece halkta bir bilinçlenme oluşturulmakta, aynı zamanda tarih şuuru aşılanmaktadır.

Tablo 3. Türkiye'deki bazı hüzün turizmi alanları (Doğaner, 2006; Kaya, 2006; Robb, 2009; Kılıç ve Akyurt, 2011; Kılıç ve Sop, 2011; Kurnaz vd., 2013; Kurnaz, Çeken ve K1lıç, 2013; Birdir vd., 2015; Varol, 2015; Kurnaz ve Kılıç, 2016; Öztürk, 2016; Alılı, 2017; Çelik, 2017; Hıdır ve Somuncu, 2018).

\begin{tabular}{|c|c|c|c|c|c|}
\hline No & Kategori & Alan & Şehir/Bölge & Ziyaretçi & Kapsam \\
\hline 1 & Doğal Afet & $\begin{array}{l}\text { Adapazar1 } \\
\text { Deprem Kültür } \\
\text { Müzesi }\end{array}$ & Adapazarı & 42 bin & $\begin{array}{l}\text { 1999'da meydana gelen Marmara } \\
\text { Depremi'nde hayatını kaybedenler } \\
\text { anısına inşa edilmiştir. }\end{array}$ \\
\hline 2 & Önemli Kişi & Anitkabir & Ankara & 6.5 milyon & $\begin{array}{l}\text { Ankara'nın Çankaya ilçesinde } \\
\text { bulunan ve içerisinde Mustafa } \\
\text { Kemal Atatürk'ün anıt mezarının yer } \\
\text { aldığı yapıdır. }\end{array}$ \\
\hline 3 & Önemli Kişi & $\begin{array}{l}\text { Dolmabahçe } \\
\text { Sarayı }\end{array}$ & İstanbul & 1.3 milyon & $\begin{array}{l}\text { Mustafa Kemal Atatürk'ün hayata } \\
\text { gözlerini yumduğu önemli bir tarihi } \\
\text { yapıdır. }\end{array}$ \\
\hline 4 & Önemli Kişi & Mevlâna Türbesi & Konya & 3.5 milyon & $\begin{array}{l}\text { Konya ilinde bulunan ve } 1926 \\
\text { yllından beri faaliyette olan müzedir. }\end{array}$ \\
\hline 5 & Savaş/Terör & $\begin{array}{l}\text { Sarıkamış- } \\
\text { Allahuekber } \\
\text { Dağları Milli } \\
\text { Parkı }\end{array}$ & Kars & Bilgi yok & $\begin{array}{l}\text { Sarıkamış Harekâtı sırasında } \\
\text { şehit düşen } 78 \text { bin Türk askeri } \\
\text { anısına ilan edilmiştir. }\end{array}$ \\
\hline 6 & Savaş/Terör & $\begin{array}{l}\text { Gelibolu } \\
\text { Yarımadası, } \\
\text { Çanakkale } \\
\text { Savaşları ve } \\
\text { Şehitlikleri }\end{array}$ & Çanakkale & $\begin{array}{l}2.5 \\
\text { milyon }\end{array}$ & $\begin{array}{l}\text { 1915-1916 yılları arasında } \\
\text { Gelibolu Yarımadası'nda } \\
\text { gerçekleşen deniz ve kara } \\
\text { muharebelerinde birçok insan } \\
\text { yaşamını yitirmiştir. }\end{array}$ \\
\hline 7 & Savaş/Terör & $\begin{array}{l}\text { Rüsumat } \\
\text { Gemisi Kıyı } \\
\text { Düzenlemesi }\end{array}$ & Ordu & Bilgi yok & $\begin{array}{l}\text { Millî Mücadele sırasında önemli } \\
\text { hizmetleri olan ve } 1921 \text { yılında } \\
\text { Yunan gemileri tarafından } \\
\text { batırılan Rüsumat No.4 isimli } \\
\text { gemi anısına yapılmıştır. }\end{array}$ \\
\hline 8 & Savaş/Terör & $\begin{array}{l}\text { Başkomutan } \\
\text { Tarihi Milli } \\
\text { Parkı }\end{array}$ & $\begin{array}{l}\text { Afyonkarah } \\
\text { isar }\end{array}$ & Bilgi yok & $\begin{array}{l}\text { Millî Mücadele'de önemli } \\
\text { çarpışmalara sahne olan bir } \\
\text { bölgededir. Alan içerisinde } \\
\text { şehitlikler, anıtlar ve müze } \\
\text { bulunmaktadır. }\end{array}$ \\
\hline
\end{tabular}


Tablo 3. Devam ediyor.

\begin{tabular}{|c|c|c|c|c|c|}
\hline No & Kategori & Alan & Şehir/Bölge & Ziyaretçi & Kapsam \\
\hline 9 & Savaş/Terör & $\begin{array}{l}\text { Nenehatun } \\
\text { Tarihi Milli } \\
\text { Parkı }\end{array}$ & Erzurum & Bilgi yok & $\begin{array}{l}\text { "93 Harbi" olarak da bilinen } \\
\text { 1877-1878 Osmanlı-Rus } \\
\text { savaşına katılan Kahraman Türk } \\
\text { kadını Nene Hatun anısına ilan } \\
\text { edilmiştir. }\end{array}$ \\
\hline 10 & Savaş/Terör & $\begin{array}{l}\text { Troya Savaş } \\
\text { Alanı }\end{array}$ & Çanakkale & 600 bin & $\begin{array}{l}\text { Çanakkale ili Hisarlık bölgesinde } \\
\text { yer alan ve Truva Savaşları'na } \\
\text { sahne olan bölgedir. }\end{array}$ \\
\hline 11 & $\begin{array}{l}\text { Toplumsal } \\
\text { Olaylar/Suç }\end{array}$ & $\begin{array}{l}\text { Tarihi Sinop } \\
\text { Cezaevi }\end{array}$ & Sinop & $\begin{array}{l}250-300 \\
\text { bin }\end{array}$ & $\begin{array}{l}\text { Tarihi Sinop Kalesi içerisinde } \\
\text { yer alan cezaevi, } 1999 \text { yılında } \\
\text { müzeye dönüştürülmüştür. }\end{array}$ \\
\hline 12 & $\begin{array}{l}\text { Toplumsal } \\
\text { Olaylar/Suç }\end{array}$ & $\begin{array}{l}\text { Çatalca } \\
\text { Mübadele } \\
\text { Müzesi }\end{array}$ & İstanbul & Bilgi yok & $\begin{array}{l}\text { Lozan Antlaşması gereği zorunlu } \\
\text { göçe tabi tutulan insanların } \\
\text { yaşadığı zorlukları anlatan çeşitli } \\
\text { objeler sergilenmektedir. }\end{array}$ \\
\hline 13 & $\begin{array}{l}\text { Toplumsal } \\
\text { Olaylar/Suç }\end{array}$ & $\begin{array}{l}\text { Yassiada } \\
\text { (Demokrasi ve } \\
\text { Özgürlükler } \\
\text { Adası) }\end{array}$ & Yassiada & Bilgi yok & $\begin{array}{l}27 \text { Mayıs } 1960 \text { Darbesi'nin } \\
\text { ardından, "Yassıada } \\
\text { Yargılamaları” olarak bilinen } \\
\text { sürecin yaşandığı adadır. }\end{array}$ \\
\hline 14 & $\begin{array}{l}\text { Toplumsal } \\
\text { Olaylar/Suç }\end{array}$ & $\begin{array}{l}\text { Ulucanlar } \\
\text { Cezaevi } \\
\text { Müzesi }\end{array}$ & Ankara & $\begin{array}{l}1 \\
\text { milyonun } \\
\text { üzerinde } \\
\text { (toplam) }\end{array}$ & $\begin{array}{l}1925 \text { ve } 2006 \text { yılları arasında } \\
\text { Ulucanlar semtinde (Ankara) } \\
\text { faaliyet gösteren cezaevidir. } \\
\text { Sonrasında müze de kültür sanat } \\
\text { merkezi olarak düzenlenmiştir. }\end{array}$ \\
\hline 15 & $\begin{array}{l}\text { Toplumsal } \\
\text { Olaylar/Suç }\end{array}$ & $\begin{array}{l}\text { Ermeniler } \\
\text { Tarafindan } \\
\text { Katledilen } \\
\text { Şehit Türkler } \\
\text { Müzesi }\end{array}$ & Iğdır & 48 bin & $\begin{array}{l}\text { 1915-1920 yılları arasında Iğdır } \\
\text { ve köylerinde katledilen halkın } \\
\text { anısına inşa edilen müzedir. }\end{array}$ \\
\hline 16 & $\begin{array}{l}\text { Toplumsal } \\
\text { Olaylar/Suç }\end{array}$ & $\begin{array}{l}15 \text { Temmuz } \\
\text { Şehitler Anıtı } \\
\text { ve Müzesi }\end{array}$ & İstanbul & Bilgi yok & $\begin{array}{l}15 \text { Temmuz } 2016 \text { yılındaki darbe } \\
\text { girişimine karşı halkın } \\
\text { direnişinin sembolü ve şehitlerin } \\
\text { anısına inşa edilmiştir. }\end{array}$ \\
\hline 17 & Kaza & $\begin{array}{l}\text { Soma Faciası } \\
\text { Alanları }\end{array}$ & Manisa & Bilgi yok & $\begin{array}{l}2014 \text { yılında Manisa ilinin Soma } \\
\text { ilçesinde bulunan kömür } \\
\text { madeninde } 301 \text { madencinin } \\
\text { ölümüyle sonuçlanan madencilik } \\
\text { kazasıdır. }\end{array}$ \\
\hline
\end{tabular}
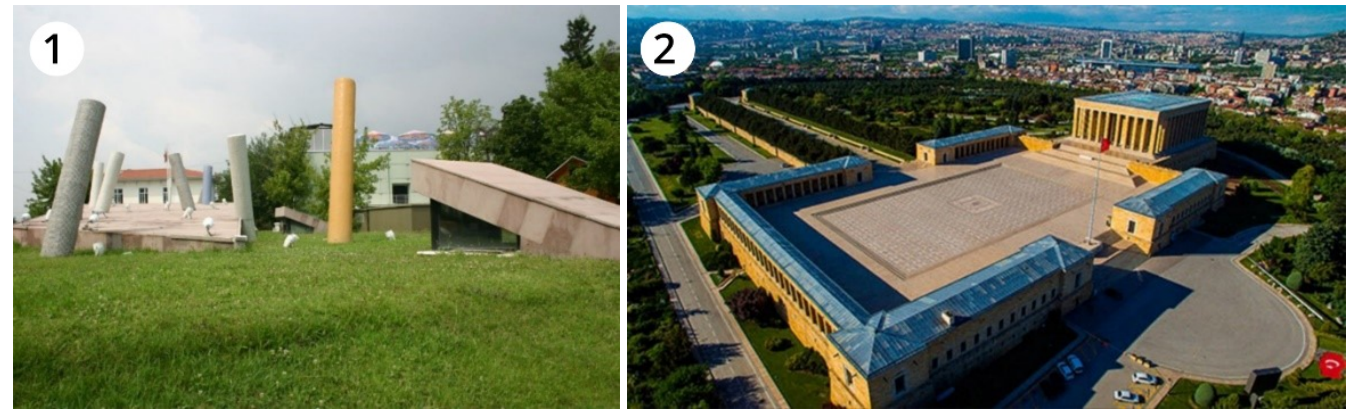

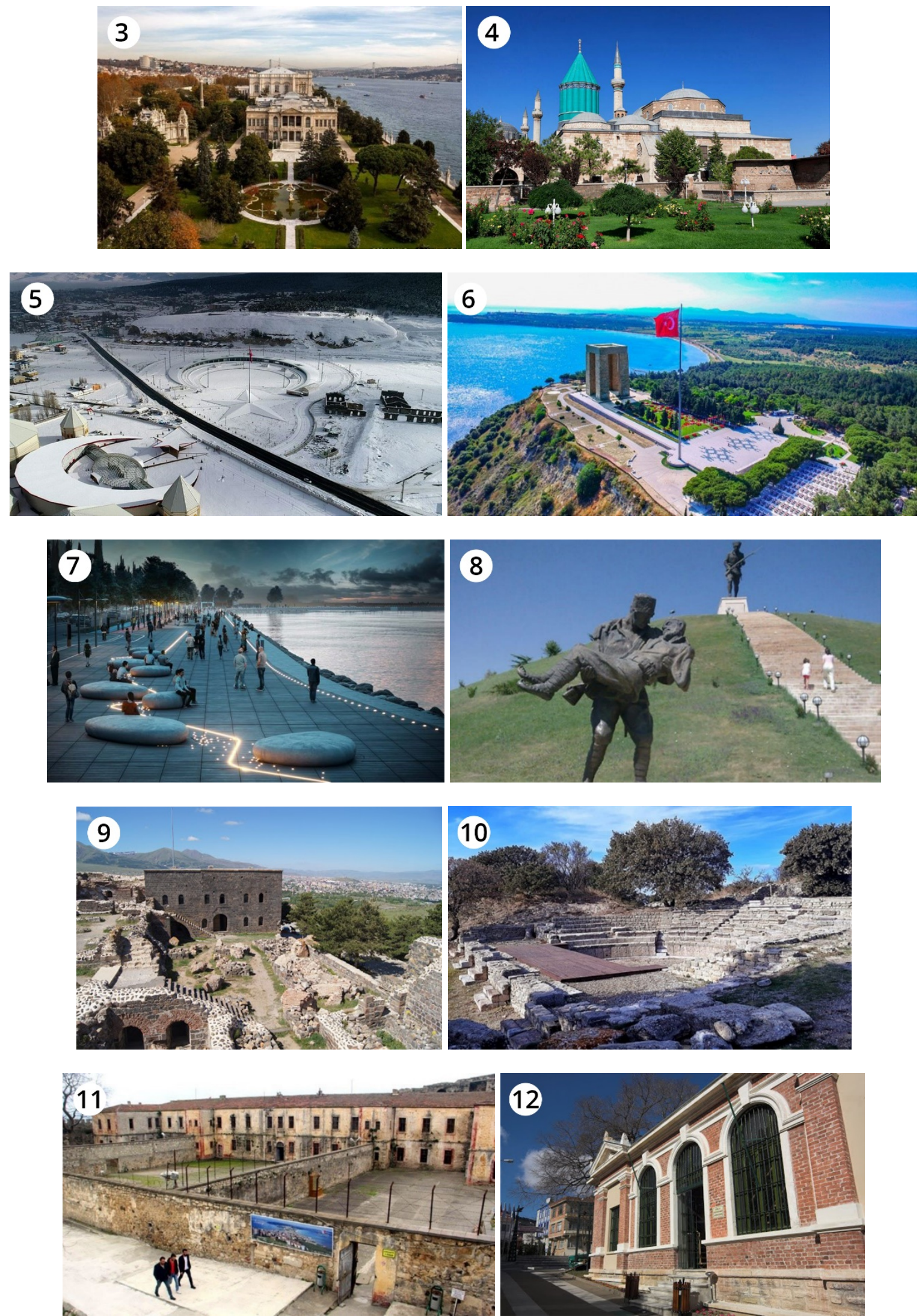

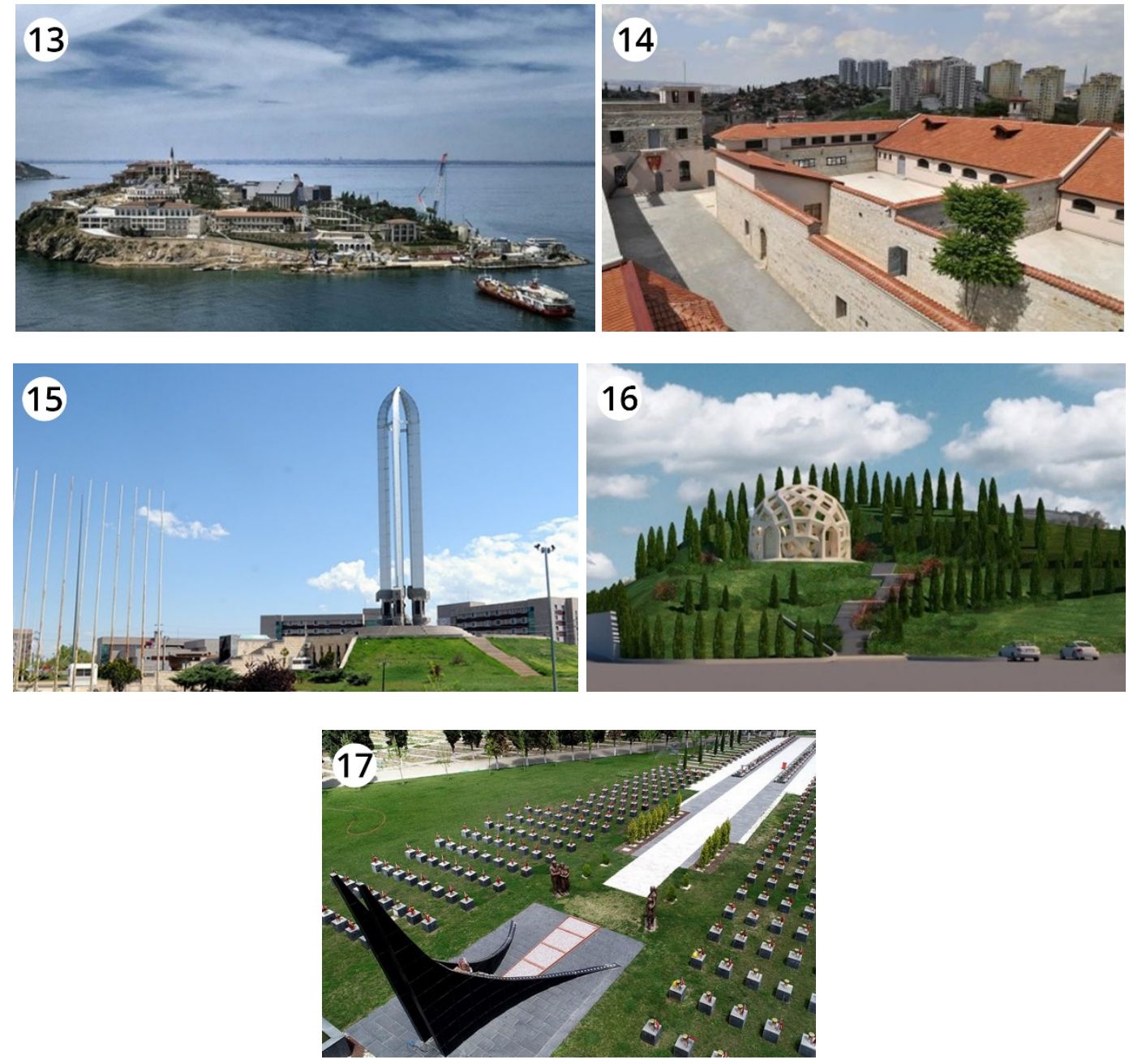

Şekil 2. Türkiye’deki bazı hüzün turizmi alanları (URL 18-35).

\section{Sonuç}

Keder, acı, korku ve ölüm gibi olgular insanları derinden etkilemekte ve bu tip olayların yaşandığı mekânlar insanlar tarafından yoğun ilgi görmektedir. Bunun sonucunda da bu mekânlara yönelik bir turizm hareketliliği oluşmaktadır (Kurnaz, 2013). Hüzün turizmi olarak tanımlanan bu hareketlilik alışılagelmiş seyahatlere sıra dışı bir alternatif sunmaktadır. Hüzün turizminin odağını oluşturan, bünyesinde ölüm ve acı olayların toplum belleğinde bıraktığı izleri barındıran alanlar (savaş alanı, mezarlık, şehitlik, müze, cezaevi, park vb.), toplumun geçmiş deneyimlerini ve hatıralarını barındırması yönüyle peyzaj mimarlığı disiplinindeki bellek mekânı kavramı ile örtüşmektedir. Hüzün turizmi ve bellek mekân niteliğindeki alanlarda yapılacak olan peyzaj tasarımı çalışmaları ciddi bir yaklaşım ve hassasiyet gerektirmektedir. Bu alanlarda peyzaj tasarımı gerçekleştirilirken;

- Mekânın anlam ve teması ile uyum sağlanmalı,

- Tasarımda yaratıcı fakat sade bir anlayış benimsenmeli,

- Alandaki fonksiyonlar net, doğrudan ve kolay algılanabilir olmalı,

- Konu odağından uzaklaşılmamalı,

- Konuya vurgu yapmalı ve konuyu desteklemeli,

- Konunun önüne geçmemeli,

- Akılda kalıcı ve iz bırakıcı olmalı,

- İfadeyi kuvvetlendirici, açıklayıcı ve tamamlayıcı olmalı,

- Milli, dini, ahlaki ve insani hassasiyetleri öncelemeli,

- Saygıyı temel almalı, ciddiyet ve resmiyetle tasarlanmalı,

- Anıt ağaç, hatıra ormanı, hatıra yolu, anıt eser, plastik obje gibi tasarım olguları ile modern insanın saygı, şükran ve acıyı paylaşma gibi duygularını ifade edecek öğeler yer almalı,

- Turizm konusunun gerektirdiği açık hava müzesi, eğitim, tören ve anma alanları gibi fonksiyonları içermeli, 
- Yapısal, bitkisel ve fonksiyonel estetik katkının yanında sembolik anlamları barındırmalı,

- Yoğun bir plantasyondan kaçınılmalı, nispeten ince tekstürlü ve görüşü engellemeyen bitkiler ile geniş çim ya da çayır alanlar tercih edilmeli,

- Mevcut siluet ve vistalar perdelenmemeli, mümkünse etkili yeni vista noktaları oluşturulmalı,

- Dinlenme, seyir ve düşünme alanları oluşturulmalıdır.

Hüzün turizmi giderek popülerleşen bir kavram olsa da özellikle ülkemizde çok fazla bilinmemektedir. Ülkemizde yapılan bazı araştırmalara göre, bireyler hüzün turizmi mekânlarına seyahat ettiği halde çoğu zaman bu seyahatin hüzün turizmi kapsamına girdiğinin bilincinde değildir. Örneğin; Çanakkale-Gelibolu'daki şehitlikler ve anıt mezarlar örneğinde yapılan bir anket araştırmasında, ziyaretçilerin ziyaretleri öncesinde alanla ilgili hiçbir ön bilgi edinmediği görülmüştür (Kurnaz, Çeken ve Kılıç, 2013). Yapılacak olan etkileyici tanıtımlarla ülkemizdeki potansiyel hüzün turizmi mekânları ziyaretçiler için cazip hale getirilebilir. Ayrıca bu mekânlardaki fiziksel koşulların iyileştirilmesi, çevresel düzenlemelerin etkili biçimde yapılması, bilgilendirme sisteminin doğru kurulması bu mekânların hizmet kalitesini arttıracaktır (Kurnaz, 2013; Kurnaz, Çeken ve Kılıç, 2013; Birdir vd., 2015; Alıl1, 2017; Çelik, 2017).

Türkiye'de çok sayıda bellek mekân ve hüzün turizmi alanı mevcuttur. Bunların çok daha bilinenleri ve toplumun tamamına mal olmuş alanlar iyi durumda, bakımlı ve etkin kullanılmakta olup, etkin bir şekilde de korunmaktadır. Hem peyzaj tasarımları hem dış mekân kullanımları çok daha özenli bir şekilde gerçekleştirilmektedir. Ancak bu ülke genelindeki ve yerel ölçekteki bellek mekânlarda sekteye uğramaktadır. Yerel yönetimlerce gerçekleștirilen koruma, bakım ve tasarım çalışmaları yetersiz kalmaktadır. Özellikle, peyzaj tasarım çalışmaları ve dış mekân kullanımları oldukça zayıftır. Bu nedenle daha küçük kentlerde hüzün turizmi ve bellek mekân kavramları daha az bilinen olgular olarak kalmaktadır. Bu da kentsel kültür ve tarih bilinci ile kent ekonomisi ve turizmine olumsuz yansımaktadır. Yurt dışı örnekleri ile kıyaslandıklarında; Türkiye'deki tüm bellek mekânların organizasyon, fonksiyon ve tasarımları açısından eşit nitelikte olmamasına karşın, yurt dışındakilerin tüm kentlerde birbirine çok yakın ve yüksek nitelikte oldukları görülmektedir. Yurtdışı örneklerinde olduğu gibi bu tip alanlara her yaştan katılımcının yer aldığı geziler düzenlenmesi, konferans ve seminer gibi tanıtıcı ve bilgilendirici toplantıların yapılması, mekânların kaynak değerleri üzerine kitap, broşür, dergi gibi yayınların hazırlanması toplumda farkındalık oluşturacaktır. Dünyanın dört bir yanından erişilebilecek, açıklayıcı ve bilgilendirici nitelikte internet sayfaları ile ülkemizdeki hüzün turizmi mekânları ve insanlık için ifade ettikleri anlamlar kolaylıkla aktarılabilir. Ayrıca bu mekânların tanıtılmasında ve gerekli çevre bakımlarının yapılmasında bir kaynak oluşturmak üzere bu internet sayfaları üzerinden bağışlar toplanabilir.

Bellek mekânların tasarımı; tarihsel, kültürel, felsefi, dini ve etik boyutları ile birlikte ele alınmalı, sofistike ve detaylı araştırmalarla olgunlaşmalıdır. Bu anlamda bellek mekânların ruhuna ve ifade ettikleri anlama uygun biçimde tasarlanmasında peyzaj mimarları kilit bir role sahiptir. Sonuç olarak bu mekânların sahip olduğu doğal, kültürel ve tarihsel değerleri korumanın yanında her gruptan ziyaretçi için de erişilebilir, estetik, işlevsel mekânlar oluşturmak amaçlanmalıdır.

\section{Kaynaklar}

1. Alaeddinoğlu, F., Aliağaoğlu, A. (2007). Savaş alanları turizmine tipik bir örnek: Büyük Taarruz ve Başkomutan Tarihî Milli Parkı. Anatolia: Turizm Araştırmaları Dergisi, 18(2), 215-225.

2. Alıl, M. (2017). Avrupa'daki ve Türkiye'deki hüzün turizmi destinasyonlarının karşılaş̧ırılması üzerine teorik bir çalışma. Uluslararası Global Turizm Araştırmaları Dergisi, 1(1), 37-50.

3. Alılı, M. (2018). Bir Hüzün Turizmi Destinasyonu Olarak Azerbaycan'ın Değerlendirilmesi. Yüksek Lisans Tezi, SDÜ Sosyal Bilimler Enstitüsü, Turizm İșletmeciliği Anabilim Dalı, Isparta, 134 s.

4. Assmann, J. (2015). Kültürel Bellek Eski Yüksek Kültürlerde Yazl, Hatırlama ve Politik Kimlik. Ayrıntı Yayınları: İstanbul, 368 sayfa.

5. Atalay, N. (2018). Savaş ve ölüm olguları bağlamında anma mekânları: Gelibolu Yarımadası, Tirgu Jiu Park1, Vietnam Gazileri Anıtı. İdil Dergisi, 7(52), 1499-1506.

6. Atik, A., Bilginer Erdoğan, Ş. (2014). Toplumsal Bellek ve Medya. Atatürk İletişim Dergisi, 6, 1-16.

7. Birdir K., Dalgıç A., Güler O., Kayaalp Y. (2015). Hüzün turizmi: Gelibolu Yarımadası Tarihi Milli Park1'nı ziyaret eden yabanc1 turistlerin deneyimleri. Journal of Tourism and Gastronomy Studies, 3(4), $12-$ 23.

8. Blom, T. (2000). Morbid tourism- a postmodern market niche with an example from Althorp. Norsk Geografisk Tidsskrift, 54(1), 29-36.

9. Chang, T. Y. (2014). Dark tourism the effects of motivation and environmental attitudes on the benefits of experience. Revista Internacional de Sociología, 72(2), 69-86. 
10. Çelik, A. (2017). Hüzün turizmi üzerine bir derleme. Türk Turizm Araştırmaları Dergisi, 1(3), 41-55.

11. Çetinsöz, B. C., Temiz, G. (2016). Alternatif bir turizm türü olarak Türkiye'nin karanlık (dark) turizm potansiyeli. International Multidisciplinary Congress of Eurasia, 2(3), 507-517.

12. Doğaner, S. (2006). Savaş ve turizm: Troya ve Gelibolu savaş alanları. Türk Coğrafya Dergisi, 46, 1-21.

13. Erbaş Gürler, E., Özer, B. (2013). The effects of public memorials on social memory and urban identity. Procedia-Social and Behavioral Sciences, 82, 858-863.

14. Gürel, E., Muter, C. (2007). Psikomitolojik terimler: Psikoloji literatüründe mitolojinin kullanılması. Sosyal Bilimler Dergisi, 1, 537-569.

15. Günaçan, S. ve Erdoğan, E. (2018). Peyzaj mimarlığı ve hafıza mekânları: İstanbul, Tarihi Yarımada örneği. Mimarlık Bilimleri ve Uygulamaları Dergisi (MBUD), 3(1), 34-53.

16. Hartmann, R. (2014). Dark tourism, thanatourism, and dissonance in heritage tourism management: New directions in contemporary tourism research. Journal of Heritage Tourism, 9(2), 166-182.

17. Hıdır, C., Somuncu, M. (2018). Auschwitz-Birkenau Anıt ve Müzesi’nin (Polonya) Hüzün Turizmi Kapsamında Değerlendirilmesi, TÜCAUM 30. Yıl Uluslararası Coğrafya Sempozyumu, Ankara.

18. Kansteiner, W. (2002). Finding meaning in memory: A methodological critique of collective memory studies. History and Theory, 41 (2), 179-197.

19. Kaya, O. (2006). Ölüm Turizmi: Gelibolu Yarımadası Tarihi Milli Parkı'nı Ziyaret Eden Turistlerin Ziyaret Motivasyonlarını Anlamaya Yönelik Bir Araştırma ve Sonuçları. Yüksek Lisans Tezi, Çanakkale Onsekiz Mart Üniversitesi Sosyal Bilimler Enstitüsü, Çanakkale, 108 s.

20. Kendle, A. (2008). http://www.vagabondish.com/dark-tourism-travel-tours, Dark Tourism: A Fine Line Between Curiousity and Exploitation, (02.07.2019).

21. Keskin, N. (2014). Kentlerde yeni bellek mekânları: Kent müzeleri. Folklor/edebiyat, 20(79), 25-39.

22. Kılıç, B., Akyurt, H. (2011). Destinasyon imajı oluşturmada hüzün turizmi: Afyonkarahisar ve Başkomutan Tarihi Milli Parkı. Gaziantep Üniversitesi Sosyal Bilimler Dergisi, 10(1), 209-232.

23. Kılıç, B., Sop, S. A. (2011). Hüzün turizmi, katarsis ve alternatif katarsistik bir destinasyon örneği olarak San Jose Madeni. Seyahat ve Otel İsletmeciliği Dergisi, 8(3), 6-22.

24. Kozak, A. M., Bahçe, S. A. (2012). Özel İlgi Turizmi. Detay Yayıncılık: Ankara, 320 s.

25. Kurnaz, H. A., Çeken, H., Kılıç, B. (2013). Hüzün turizmi katılımcılarının seyahat motivasyonlarının belirlenmesi. İşletme Araştırmaları Dergisi, 5(2), 57-73.

26. Kurnaz, H. A., Kılıç, B. (2016). İtici ve Çekici Faktörlerin Hüzün Turizmi Destinasyonlarında Memnuniyet ve Sadakate Etkisi: Çanakkale Örneği. Çankırı Karatekin Üniversitesi Sosyal Bilimler Enstitüsü Dergisi, 7(2), 139-164.

27. Kurnaz, H. A. (2013). Hüzün Turizminin İç Turizme (İç Turizm Talebine) Etkisi: Çanakkale Örneği. Yüksek Lisans Tezi, Muğla Sıtkı Koçman Üniversitesi Sosyal Bilimler Enstitüsü, Muğla, 72 s.

28. Lennon, J., Foley, M. (2000). Dark Tourism - The Attraction of Death and Disaster, Continuum: London, 256 pages.

29. Mert, G. (2017). Organizasyonlarda Bireysel Hafiza. Artikel Yayıncılık: İstanbul, 94 s.

30. Nora, P. (2006). Hafiza Mekânları (çev.: M. Emin Özcan), Dost: Ankara, 263 s.

31. Okuyucu, A., Erol, F. (2018). Savaş alanları turizmine yönelik motivasyon, duygu ve deneyimler: Metristepe ve İnönü Şehitlikleri-Bozüyük örneği. Coğrafi Bilimler Dergisi, 16(1), 135-151.

32. Öymen Özak, N., Pulat Gökmen, G. (2009). Bellek ve mekân ilişsisi üzerine bir model önerisi. ITÜDERGISİ/a, 8(2), 145-155.

33. Öztürk, A. (2016). Hüzün Turizmi Katılımcılarının Kişilik Özellikleri, Motivasyonları ve Memnuniyetleri Arasındaki İlişki. Yüksek Lisans Tezi, Akdeniz Üniversitesi Sosyal Bilimler Enstitüsü, Antalya, 124 s.

34. Robb, E. M. (2009). Violence and recreation: Vacationing in the realm of dark tourism. Anthropology and Humanism, 34(1), 51-60.

35. Seaton, A. V. (1996). From thanatopsis to thanatourism: Guided by the dark. International Journal of Heritage Studies, 2, 234-244.

36. Stone, P., Sharpley, R. (2008). Consuming dark tourism: A thanatological perspective. Annals of Tourism Research, 35(2), 574-595.

37. Taşören, A. B. (2008). Bellek ve Öğrenmenin Geniş Kapsamlı Ölçümü ile Geniş Kapsamlı Başarı Testinin Geçerlilik, Güvenilirliği ve Dokuz Yaş Çocuklarında Değerlendirilmesi. Doktora Tezi, Marmara Üniversitesi Eğitim Bilimleri Enstitüsü, İstanbul, $238 \mathrm{~s}$.

38. TDK (2019). http://sozluk.gov.tr, Güncel Türkçe Sözlük- Bellek, (25.06.2019).

39. Ünlü, T. S. (2017). Kent kimliğinin oluşumunda kentsel bellek ve kentsel mekân ilişkisi: Mersin örneği. Planlama Dergisi, 27(1), 75-93.

40. URL-1 (2018). https://2018.911memorial.org, Annual Report National September 11 Memorial \& Museum, (21.09.2019).

41. URL-2. https://www.tiqets.com/blog/visiting-pompeii/ Visiting Pompeii: Your Ultimate Guide to the Lost City, (13.05.2021). 
42. URL-3. https://www.neoldu.com/anne-frankin-evi-ozellikleri-ve-hakkinda-bilgi-33408h.htm Anne Frank'ın Evi Özellikleri ve Hakkında Bilgi, (13.05.2021).

43. URL-4. http://mimdap.org/2014/06/ulusal-11-eylul-anyty-ve-pavyonu-snohetta/ Ulusal 11 Eylül anıtı ve pavyonu: Snohetta, (13.05.2021).

44. URL-5. https://tr.euronews.com/2018/07/12/yakin-tarihin-utanci-srebrenitsa-katliami-kurbanlarin-definislemleri-hala-suruyor Srebrenitsa Soykırımı 23. yılında anıldı, (13.05.2021).

45. URL-6. https://www.aa.com.tr/tr/dunya/hirosimada-anma-toreni/227412 Hiroşima'da anma töreni, (13.05.2021).

46. URL-7. https://listelist.com/waterloo-savasi/ Herkesçe Bilinmesi Gereken 20 Özelliğiyle Waterloo Savaş1, (13.05.2021).

47. URL-8. https://www.hisglobal.com.tr/blog/dark-turizm-nedir Dark Turizm Nedir? Dark Turizm Hakkında Merak Edilenler, (13.05.2021).

48. URL-9. https://www.sondakika.com/fotogaleri/olum-tarlalarinda-oldurulen-kambocyalilar-anildi/ Ölüm Tarlalarında Öldürülen Kamboçyalılar Anıldı, (13.05.2021).

49. URL-10. https://blog.obilet.com/krakowda-gezilecek-yerler/ Krakow’da Gezilecek Yerler, (13.05.2021).

50. URL-11. https://www.tarihiolaylar.com/tarihi-olaylar/alcatraz-federal-hapishanesi-308 Alcatraz Federal Hapishanesi, (13.05.2021).

51. URL-12. http://narcekirdekleri.blogspot.com/2013/01/berlin-yahudi-muzesi-ve-yokluk.html Berlin Yahudi Müzesi ve Yokluk, Yitilmişlik, Bellek Üzerine, (13.05.2021).

52. URL-13. https://tr.wikipedia.org/wiki/Berlin_Duvar\%C4\%B1 Berlin Duvarı, (13.05.2021).

53. URL-14. $\quad$ http://introtoarchitecturalculture.blogspot.com/2013/10/katledilen-avrupal-yahudiler-antberlin.html Katledilen Avrupalı Yahudiler An1t1, (13.05.2021).

54. URL-15. https:/www.theguardian.com/world/2020/aug/22/holocaust-denial-graffitied-at-site-of-nazimassacre-in-france (13.05.2021).

55. URL-16. https://www.ntv.com.tr/galeri/seyahat/dunyanin-en-korkutucu-yerlerinden-birisi-paris-yeraltimezarligi,5vaZa5u11Uik7ynpwhC20Q Paris Yeraltı Mezarlığı, (13.05.2021).

56. URL-17. https://onedio.com/haber/uyumadan-once-okumayin-cernobil-faciasi-ile-ilgili-daha-once-hicbiryerde-duymadiginiz-birbirinden-urkutucu-21-gercek-876115 Çernobil Faciası, (13.05.2021).

57. URL-18. https://www.aa.com.tr/tr/dunya/batik-geminin-kaptani-konustu/356343 Costa Concordia, (13.05.2021).

58. URL-19. https://lifesakarya.com/turkiyedeki-ilk-deprem-muzesi/ Türkiye’deki ilk deprem Müzesi, (13.05.2021).

59. URL-20. https://www.haberturk.com/video/haber/izle/anitkabir-ilk-kez-boyle-goruntulendi/335334 Anitkabir, (13.05.2021).

60. URL-21. https://twitter.com/millisaraylar/status/1191731632417497088/photo/1 Dolmabahçe Saray1, (13.05.2021).

61. URL-22. https://www.gezgezinsani.com/mevlana-muzesi/ Mevlana Müzesi ve Türbesi, (13.05.2021).

62. URL-23. https://www.aa.com.tr/tr/turkiye/ay-yildizli-toren-alani-sarikamis-sehitleri-anma-programinahazir/1688402 Sarıkamış Şehitleri Anıtı, (13.05.2021).

63. URL-24. $\quad$ https://www.canakkalekalem.com/wp-content/uploads/2020/04/\%C3\%87anakkale\%C5\%9Eehitli\%C4\%9Fi-ve-\%C5\%9Eehitler-Abidesi-5-700x420-1.jpg Çanakkale Savaşları ve Şehitlikleri, (13.05.2021).

64. URL-25. https://www.arkitera.com/wp-content/uploads/2018/05/CA_Rust_C01F01.jpg-615x375.jpeg Rüsumat Gemisi Kıyı Düzenlemesi, (13.05.2021).

65. URL-26. https://i4.hurimg.com/i/hurriyet/75/750x422/5862d29b18c77311887d4937.jpg Başkomutan Tarihi Milli Park1, (13.05.2021).

66. URL-27. http://nenehatun.tabiat.gov.tr/ Nenehatun Tarihi Milli Park1, (13.05.2021).

67. URL-28. https://www.rehbername.com/seyahat/troya-antik-kenti Troya Savaş Alanı, (13.05.2021).

68. URL-29. Tarihi Sinop Cezaevi https://www.ntv.com.tr/seyahat/anadolunun-alkatrazi-tarihi-sinopcezaevi,NGVymfl4N0uWtWsXKcPbcw, (13.05.2021).

69. URL-30. http://www.lozanmubadilleri.org.tr/catalca-mubadele-muzesi// Çatalca Mübadele Müzesi, (13.05.2021).

70. URL-31. https://i2.milimaj.com/i/milliyet/75/1200x675/5ecd14a855428014e0a40ee8.jpg Yassiada (Demokrasi ve Özgürlükler Adas1), (13.05.2021).

71. URL-32. https://www.arkitera.com/haber/ulucanlar-cezaevi-muzesi-halka-acildi/ Ulucanlar Cezaevi Müzesi, (13.05.2021).

72. URL-33. https://www.trthaber.com/haber/turkiye/ermeni-katliaminin-izleri-anit-mezarda-sergileniyor180053.html Ermeniler Tarafindan Katledilen Şehit Türkler Müzesi, (13.05.2021).

73. URL-34. http://img.gazetevatan.com/vatanmediafile/Haber598x362/2017/07/10/iste-15-temmuz-sehitlerabidesi-nin-detaylari-2960298.Jpeg 15 Temmuz Şehitler Anıtı ve Müzesi, (13.05.2021). 
74. URL-35. https://www.nedenben.com/haberler/soma-faciasi-sehitleri-5--yilinda-aniliyor Soma Facias1 Anit1, (13.05.2021).

75. Varol, F. (2015). Hüzün Turizminin Türkiye'de Var Olan Potansiyeli Üzerine Kuramsal Bir Araştırma, I. Eurasia International Tourism Congress: Current Issues, Trends, and Indicators, 147-160, 28-30 May1S 2015, Konya.

76. Wertsch J. V., Roediger H. L. (2008). Collective memory: conceptual foundations and theoretical approaches. Memory, 16(3), 318-32.

77. Yıldız Z., Yıldız S., Aytemiz L. (2015). Kara turizm, terör turizmi ve Türkiye potansiyeli, insan ve toplum bilimleri. Araştırmaları Dergisi, 4 (2), 390-407.

78. Yuill, S. M. (2003). Dark Tourism: Understanding Visitor Motivation at Sites of Death and Disaster. Master's Thesis, A\&M University, Texas, 265 s. 